\title{
Feasibility of Community Management of Miombo Woodlands for Carbon Project in Southern Highlands of Tanzania
}

\author{
Z. J. Lupala, ${ }^{1}$ L. P. Lusambo, ${ }^{2}$ and Y. M. Ngaga $^{2}$ \\ ${ }^{1}$ Ministry of Natural Resources and Tourism, Forestry Training Institute, Arusha, Tanzania \\ ${ }^{2}$ Forest Economics, Sokoine University of Agriculture, Morogoro, Tanzania \\ Correspondence should be addressed to Z. J. Lupala; zachlupala@yahoo.com
}

Received 4 March 2017; Revised 29 May 2017; Accepted 18 June 2017; Published 7 August 2017

Academic Editor: Daniel I. Rubenstein

Copyright (c) 2017 Z. J. Lupala et al. This is an open access article distributed under the Creative Commons Attribution License, which permits unrestricted use, distribution, and reproduction in any medium, provided the original work is properly cited.

\begin{abstract}
In response to the pressing global challenges of climate change, community based management of miombo woodlands in Tanzania is promoted for carbon credit project development. However, evidence on its feasibility is scanty and questionable. This study examined the economic feasibility of carbon credit project development in community based forest management (CBFM) using four similar miombo woodlands from Southern highlands. The analysis was based on 144 sample plots from managed woodlands and 100 plots from business as usual (BAU) (open access). Allometric equation was applied to convert biomass to carbon per hectare. Improved carbon stock was determined and its economic value ascertained based on global voluntary carbon markets. Project feasibility analysis was performed using discounted cash flow, internal rate of return, and benefits/costs methods. Annual opportunity cost and variable costs were subtracted from total revenue to obtain annual net profit. The annual rate of return on investment was calculated by dividing profits by total costs. It was revealed that carbon stock improved significantly in CBFM compared to BAU $(P<5 \%)$. The improvement had positive net present value and benefit-cost ratio of 1.83 . Moreover, sensitivity analysis showed that if any unexpected situation occurs, the project will still be of worthiness. The findings are useful to enrich the debate on carbon credit development under community based management of miombo woodlands in Tanzania.
\end{abstract}

\section{Introduction}

Miombo woodland is among the most important ecosystems for socioeconomic and environmental roles $[1,2]$. It is home to megafauna assemblage and among the world's highbiodiversity hotspots $[3,4]$. The role of miombo woodland in global carbon cycle is increasingly recognized [2, 58]. Between 0.5 and 0.9 tons of carbon $\mathrm{ha}^{-1}$ year $^{-1}$ are being sequestered in miombo woodland, with maximum sequestration in young miombo $[5,8,9]$. Moreover, livelihoods of significant number of people depend on miombo woodland through provision of many products and services [10]. Unfortunately, its capacity to provide these products and services is decreasing rapidly each year due to deforestation and forest degradation [11].

The increasing rate of deforestation and forest degradation is a major concern for many countries in the world [11]. For example in Tanzania, the extent of deforestation and forest degradation is devastating, about $372,816 \mathrm{ha} /$ year [12].
Miombo woodland suffers the most if compared to other tropical forest biomes $[11,13,14]$. This raised necessity to promote sustainable forest management through community based forest management $[10,15]$. Community based forest management (CBFM) was developed to combat deforestation and promote sustainable forest management in developing countries [16-18]. The underlying principle is that communities can be best positioned to manage and protect forest resources provided it is their interest to do so $[17,19]$ (Larson, 2004).

Through CBFM, local communities establish clear rules for sustainable resource use and respond to deforestation signals more rapidly [2,20]. This is important for the successful management of African miombo woodlands. According to Dewees et al. [10], sustainable management of miombo woodlands is important for three reasons: (i) they sequester enormous amounts of carbon; (ii) they support livelihoods to millions of people and provide a renewable source of energy, that is, fuel wood and charcoal; and (iii) their successful 
management would contribute to poverty alleviation by supporting and strengthening local livelihood strategies. In times of stress these woodlands serve as an insurance against famine by offering a source of wild foods and fruits and other useful products $[10,21]$.

By virtue of involving local forest users under CBFM, there is widely reported improvement of forest condition, social cohesion, and rural incomes in Tanzania and elsewhere (e.g., see [22-25] (Antinori and Rausser, 2008)). This has attracted the United Nation program on Reduced Emission from Deforestation and Forest Degradation and the role of conservation, sustainable management, and enhancement of carbon stock (REDD+) to adopt CBFM as an important toolkit [26]. Indeed, this is an important framework for sustainable forest management and climate change mitigation in many developing countries including Tanzania [27].

REDD+ is expected to bring about economic development through transfer of payments, reduce poverty, and boost capacity of developing countries to mitigate climate change $[1,28]$. If successful, carbon mitigation projects can produce cobenefits by conserving biodiversity, ecosystem services, improving forest governance, and the welfare of forest dependent communities [26, 29]. This potential, however, has not been well taped in miombo woodlands of Tanzania and its evidence base was found to be weak and questionable (Behera, 2009; Bowler et al., 2012).

Furthermore, there are increasing doubts over the viability and effectiveness of CBFM for carbon project development [30-32]. The main concern is that benefits from carbon project development may not be sufficient to cover various costs imposed on local communities [30, 33]. Rigorous literature review has shown that there is a need for feasibility analysis on carbon project development possibilities in miombo woodlands of Tanzania [2]. This will ensure better-informed policy direction, strategy, and practice which guarantee climate change mitigation and livelihood options $[2,26]$. The need for feasibility analysis of CBFM for carbon project development in order to support informed judgment and decision making about its merit is important (e.g., [3032]).

Whether the project shall contribute to the future improvement in social and economic welfare of the community and promotes sustainable forest management needs to be addressed. "This is a key motivation for economic feasibility analysis of carbon project development in community based managed miombo woodlands and their subsequent implications for sustainable forest management in Tanzania." According to Angelsen et al., [28] the economic viability of this kind of projects may depend on meeting important criteria such as effectiveness, efficiency, equity, and cobenefits $(3 \mathrm{E}+)$.

Effectiveness requires that net carbon emission reductions should be positive and significant. Likewise the stored carbon needs to be "additional" if compared to business as usual scenario [28]. Efficiency implies that emission reductions are less costly relative to other options. This implies that carbon benefits should be greater than the costs borne by different stakeholders to make this instrument incentive-compatible [35]. Equity implies issues of social
TABLE 1: Land use categories and criteria used in selection of study sites.

S/N Category Criteria for selection

(i) Management plan and by-laws for forest management activities

(ii) Experience from expert opinion that the forest is under CBFM

1

CBFM (iii) Patrols and management meetings explaining management activities

(iv) Presence of Village Environmental Committee (VEC) taking care of the forest

(v) Tree vegetation comprise miombo woodlands

(i) No records of forest management activities

(ii) Located adjacent to CBFM and tree composed of miombo woodlands

$2{ }^{*}$ BAU (iii) Open access for local use and extraction of resources is unregulated

(iv) Experience from expert that nothing have been done to regulate forest extraction

\footnotetext{
${ }^{*}$ Business as usual is a projections of future emission levels in the absence of any policy changes or REDD activities [34] while with CBFM the laws are enforced by community and sustainable use controlled.
}

justice (fairness and rights) associated with implementation of the REDD+ projects at local levels [36]. Together with biodiversity conservation implications, all these are referred to as cobenefits of REDD+ projects [28]. The understanding is useful for project developers initiating carbon project and also informs climate change mitigation strategies such as those triggering development of economic incentives for promotion of sustainable forest management.

\section{Materials and Methods}

This study examined the economic feasibility of carbon project development based on the extent of carbon stock in CBFM of miombo woodland relative to a business as usual scenario in Southern Highlands of Tanzania. A counterfactual design of identifying matching treatment (CBFM) and control groups (BAU) based on similarities in observed characteristics was used [31]. This was based on assumption that treatment and control are not related to other factors that may have determined outcome (Ferraro, 2009). Community based managed miombo woodland (CBFM) and its adjacent business as usual (BAU) land use categories were selected using specific criteria and land use characteristics. In order to ensure a set of statistically matching comparison, however, the criteria such as similar topographical and forest characteristics, socioeconomic forest use, infrastructure, and market access were established (Table 1).

In addition, geographic proximity and historical and ecological information were used to separate the effects of management from those of possible confounding factors. With this in mind, four CBFM managed miombo woodlands and three adjacent reference scenarios in Mufindi and Iringa rural districts of southern highlands of Tanzania were studied (Table 2 and Figure 1). 


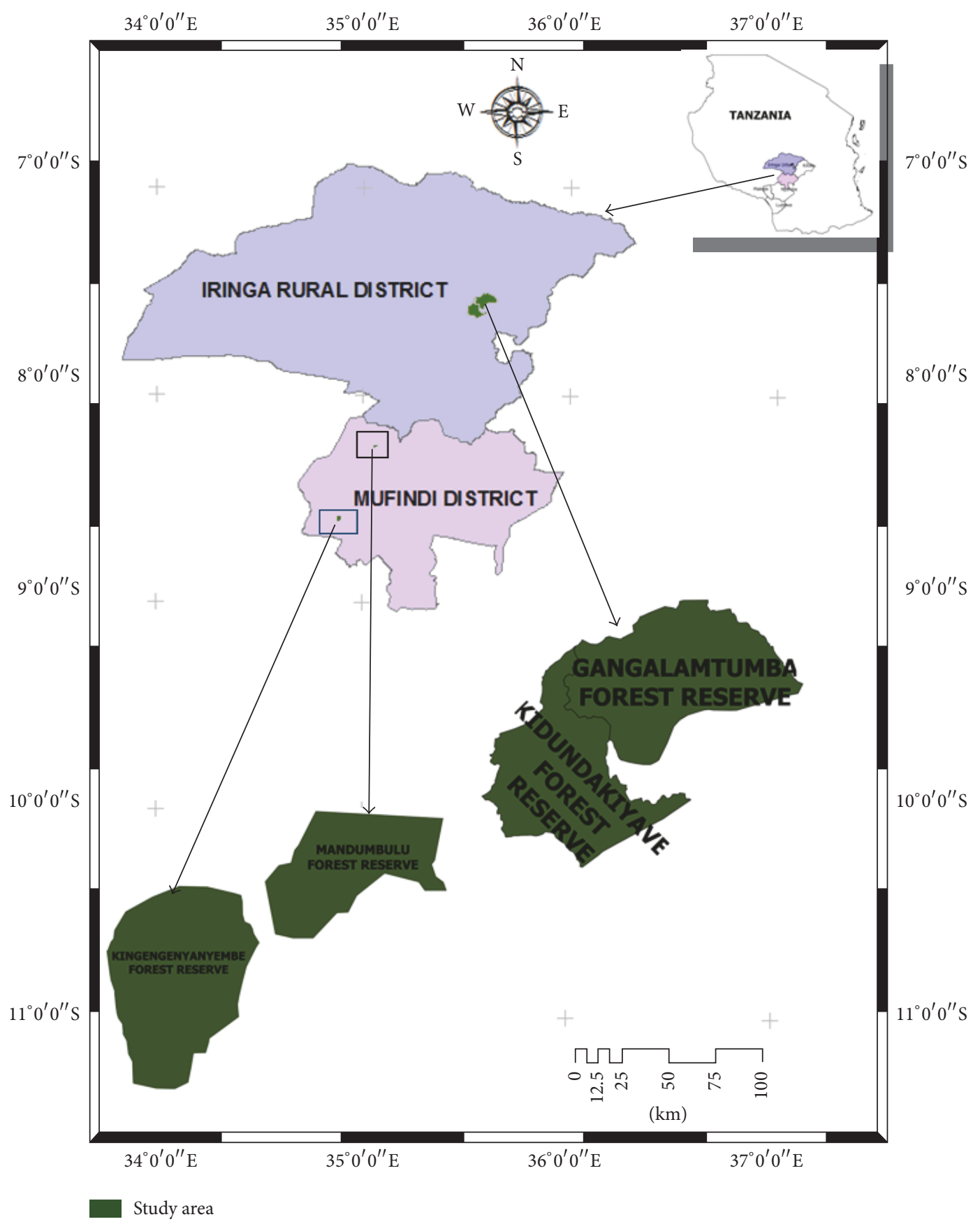

FIGURE 1: Geographical location of study districts and respective studied forest reserves of Southern Highlands of Tanzania.

2.1. Data Collection and Analysis. The procedure for forest inventory was based on MacDicken [37], MNRT [38], and from good practice guidance for land use, land use change, and forestry [39]. Required number of sample plots was determined through $n=\left(\mathrm{CV}^{2} * t^{2}\right) / E^{2}=\left((\mathrm{SD} / X)^{2} * t^{2}\right) / E^{2}$, where $\mathrm{CV}$ is coefficient of variation; $t$ the value from the students' distribution table at $n-1$ degrees of freedom, SD standard deviation, $X$ mean of basal area, and $E$ precision, and in this case $10 \%$ error was adopted (Zahabu, 2008). The first plot was located at $100 \mathrm{~m}$ from the forest edge while subsequent plots were located systematically along transect lines at intervals of $200 \mathrm{~m}$. This helped to cover gradients, species composition, and structural characteristics. Concentric circular plot with a maximum radius of $15 \mathrm{~m}$ was used for the aim of increasing the accuracy of the measurement and sampling intensity of various tree sizes and to save time [12]. In each sample plot (0.07 ha), plot number, slope, aspect, vegetation type, and coordinates were recorded to help in characterization of the woodlands. In total, 244 sample plots were examined, including 100 plots in business as usual as reference scenario. In each plot, Radius $2 \mathrm{~m}$ is measured and recorded diameter of all trees with $\mathrm{DBH} \geq 1 \mathrm{~cm}$, 
TABLE 2: Location of miombo woodlands, management practices, and its climatic characteristics.

\begin{tabular}{|c|c|c|c|c|c|c|c|}
\hline District & $\begin{array}{c}\text { Name of miombo } \\
\text { under CBFM }\end{array}$ & $\begin{array}{c}\text { Name of compared } \\
\text { (BAU) }\end{array}$ & Location & Altitude (m) & $\begin{array}{l}\text { Dominant } \\
\text { soil type }\end{array}$ & $\begin{array}{c}\text { Mean } \\
\text { temp } \\
\left({ }^{\circ} \mathrm{C}\right) / \text { year }\end{array}$ & $\begin{array}{l}\text { Mean rain } \\
(\mathrm{mm}) / \text { year }\end{array}$ \\
\hline \multirow[b]{2}{*}{ Iringa rural district } & Gangalamtumba & Makota & $\begin{array}{c}7^{\circ} 35^{\prime} \mathrm{S} . \\
35^{\circ} 35^{\prime} \mathrm{E} .\end{array}$ & $850-1,300$ & $\begin{array}{l}\text { Sandy clay } \\
\text { loam soils }\end{array}$ & 19.8 & 617 \\
\hline & Kidundakiyave & Makota & $\begin{array}{l}7^{\circ} 590^{\prime} \mathrm{S} \\
35^{\circ} 79^{\prime} \mathrm{E}\end{array}$ & $850-1,300$ & $\begin{array}{l}\text { Clay alluvial } \\
\text { soils }\end{array}$ & 21.5 & 600 \\
\hline \multirow{2}{*}{ Mufindi district } & Mandumburu & Ngombe & $\begin{array}{l}8^{\circ} 43^{\prime} \mathrm{S} \\
35^{\circ} 64^{\prime} \mathrm{E}\end{array}$ & $1180-1500$ & $\begin{array}{l}\text { Sandy loam } \\
\text { soils }\end{array}$ & $24.06^{\circ} \mathrm{C}$ & 630 \\
\hline & Kingegenyanyembe & Kingegenyanyembe & $\begin{array}{l}8^{\circ} .00^{\prime} \mathrm{S} \\
35^{\circ} 15^{\prime} \mathrm{E} .\end{array}$ & $1600-1800$ & $\begin{array}{l}\text { Sand clay } \\
\text { soils }\end{array}$ & $22.56^{\circ} \mathrm{C}$ & 584 \\
\hline
\end{tabular}

Radius $5 m$ is all trees with $\mathrm{DBH} \geq 5 \mathrm{~cm}$, Radius $10 m$ is all trees with $\mathrm{DBH} \geq 10 \mathrm{~cm}$, and Radius $15 \mathrm{~m}$ is all trees with $\mathrm{DBH} \geq$ $20 \mathrm{~cm}$.

Estimation of amount of wood extraction was done at stump level. The number of felled trees was measured from stumps at $30 \mathrm{~cm}$ above ground. Three sample trees in each plot from DBH classes were randomly selected and measured for basal diameter (BD) and $(\mathrm{DBH})$ in $\mathrm{cm}$ and height $(H)$ of the metre. Measured basal diameter was determined as new stump if harvested within year 2014 (inventory year) and old if harvested in year 2013 and below based on stump conditions observed. The distinction of the age of stumps was established by the color and freshness of exposed wood, the size of sprouts/coppices, and the presence of fire scorch on exposed wood.

In each case, trees and stumps measured were identified using vernacular names with the help of knowledgeable local elders who are well acquainted with ethnobotany and aspect of wood utilization and management in the respective village. The criteria used for identification of the harvested species were coppice growth, wood and bark characteristics, and the symmetry of the stump. Moreover, focus group discussion and key informant interview were used to obtain perception and interest related to carbon project development. A feedback workshop for committee members was organized in Iringa town to discuss on how carbon project development venture might be and how they will be organized for the case of carbon project.

2.2. Estimation of Carbon Stock and Sequestration. The selection of appropriate allometric equations for computation of both aboveground biomass (AGB) and belowground biomass (BGB) was done through pretested locally available allometric equations. The general allometric equation for $\mathrm{AGB}=$ $0.1027 D^{2.4798}$ and $\mathrm{BGB}=0.2113 D^{1.9838}$ computation by Mugasha et al. [40] was used, where biomass is total tree biomass $(\mathrm{kg})$ and $\mathbf{D}$ is tree $\mathrm{dbh}(\mathrm{cm})$. This equation includes trees greater than $1 \mathrm{~cm}$ diameter at breast height $(\mathrm{dbh})$ and it has the advantage of requiring only $\mathrm{dbh}$ as an independent variable. Among others, the equation included miombo woodlands from Iringa region and also had $R^{2}$ of $95 \%$ making it most reliable. The use of local allometric equations for areas with similar geographical and vegetation type is recommended in the literature (Brown, 2003) $[39,40]$. Biomass was then converted to carbon using biomass carbon ratio of 0.48 and then multiplied by 3.67 to get equivalent $\mathrm{tCO}_{2} /$ ha [12]. In addition, the total tree volume was calculated from the allometric equation developed by Mauya et al. [41]. The equation was $\mathbf{V}=0.00016 D^{2.463}$, where $\mathbf{V}$ is tree volume $\left(\mathrm{m}^{3}\right)$ and $\mathbf{D}$ is tree dbh $(\mathrm{cm})\left(R^{2}=0.87\right)$. Diameter at breast height of stump was obtained by regression of height to basal diameter of sample trees developed $(\mathrm{Ht}=4.234+0.254(\mathrm{bd})$, $\left.R^{2}=0.78, P<0.0001\right)$.

2.3. Economic Feasibility Analysis for Carbon Project Development. This study used Benefit-Cost Analysis (BCA) as economic analysis techniques to help with the decision whether the project is worth undertaking. Economic feasibility depends on (a) existing carbon stock; (b) baseline used here referred to as business as usual to determine deforestation rate; (c) price of carbon stock avoided; (d) costs of implementation to reduced emission. The market value of carbon stock and sequestration was calculated assuming a ton of $\mathrm{CO}_{2}$ removal worth 5 USD [42]. Based on this, carbon credit was evaluated using net present value (NPV), internal rate of return, and benefit/cost ratio [43]. The cost of carbon sequestration in CBFM is the cost of improved forest management, including the cost of establishing CBFM and maintaining the system, plus the opportunity costs associated with the lost benefits of alternative systems (business as usual or open access). The costs are represented on a per-hectare basis, as are the carbon sequestration potentials.

Thus on an annual basis, the annual gross carbon income $=$ Emission avoided annually $* \$ /$ ton of carbon while annual net income from emission avoided $=$ Gross carbon income - (opportunity + transaction + management costs). Once the economic values of benefits and costs have been derived, the results were presented in three traditional forms: NPV, $\mathrm{B} / \mathrm{C}$ ratio, and internal rate of return (IRR) [44]. Sensitivity analysis for the key parameters which might have greater influence on the project development was calculated to check the effect of unexpected situation to the feasibility results.

\section{Results and Discussion}

3.1. The Observed General Condition of Studied Miombo Woodlands. The mean stem density was highest $(4118 \pm 2811$ stems $\left.\mathrm{ha}^{-1}\right)$ in Kingegenyanyembe and lowest (1982 \pm 1563 
TABLE 3: Stocking parameters in miombo woodlands based on management practices.

\begin{tabular}{lccccc}
\hline Forest name & District & Management & $N\left(\mathrm{ha}^{-1}\right)$ & $G\left(\mathrm{~m}^{2} / \mathrm{ha}^{-1}\right)$ & $V\left(\mathrm{~m}^{3} \mathrm{ha}^{-1}\right)$ \\
\hline Mandumburu & Mufindi & $\operatorname{CBFM}(n=52)$ & $2716 \pm 2169$ & $9.01 \pm 2.81$ & $1.63 \pm 1.17^{\mathrm{a}}$ \\
Ngombe & Mufindi & $\operatorname{BAU}(n=40)$ & $3216 \pm 2254$ & $10.71 \pm 4.84$ & $1.86 \pm 1.30^{\mathrm{a}}$ \\
Kingegenyanyembe & Mufindi & $\operatorname{CBFM~}(n=30)$ & $4118 \pm 2811$ & $10.59 \pm 5.37$ & $1.76 \pm 1.11^{\mathrm{a}}$ \\
Kingegenyanyembe & Mufindi & $\operatorname{BAU}(n=30)$ & $2522 \pm 1636$ & $5.14 \pm 3.09$ & $0.66 \pm 0.49^{\mathrm{b}}$ \\
Gangalamtumba & Iringa rural & $\operatorname{CBFM~}(n=30)$ & $1982 \pm 1563$ & $11.56 \pm 3.69$ & $4.51 \pm 2.42^{\mathrm{a}}$ \\
Kidundakiyave & Iringa rural & $\operatorname{CBFM~}(n=32)$ & $2655 \pm 2207$ & $9.07 \pm 2.88$ & $1.85 \pm 1.48^{\mathrm{a}}$ \\
Makota & Iringa rural & $\operatorname{BAU}(n=30)$ & $2237 \pm 2119$ & $8.45 \pm 3.98$ & $1.23 \pm 0.71^{\mathrm{b}}$ \\
\hline
\end{tabular}

Note. $n=$ sample size, $N$ is the number of stems ha ${ }^{-1}, G$ is the basal area $\left(\mathrm{m}^{2} \mathrm{ha}^{-1}\right)$, and $V$ is the volume $\left(\mathrm{m}^{3} \mathrm{ha}^{-1}\right)$; numbers after \pm are $95 \%$ confidence limits (products of standard errors of the mean and $t$-value at $95 \%$ confidence level) and means with the same letter are not significantly different using Bonferroni $t$-test $(\alpha=0.05)$.

TABLE 4: Effects of woodland management on biomass and carbon stock in studied sites.

\begin{tabular}{lcccccc}
\hline $\begin{array}{l}\text { Name of miombo } \\
\text { woodland }\end{array}$ & Management & $\begin{array}{c}\mathrm{AGB} \\
\left(\mathrm{t} / \mathrm{ha}^{-1}\right)\end{array}$ & $\begin{array}{c}\mathrm{CO}_{2} \mathrm{eq} \\
\left(\mathrm{t} / \mathrm{ha}^{-1}\right)\end{array}$ & $\mathrm{BGB}(\mathrm{t} / \mathrm{ha})$ & $\begin{array}{c}\mathrm{CO}_{2} \mathrm{eq} \\
\left(\mathrm{t} / \mathrm{ha}^{-1}\right)\end{array}$ & $\begin{array}{c}\text { Total CO} \\
(\mathrm{t} / \mathrm{ha})\end{array}$ \\
\hline Mandumburu & CBFM & $1.10 \pm 0.80$ & $2.01 \pm 1.46$ & $0.54 \pm 0.30$ & $0.99 \pm 0.54$ & $3.00 \pm 2.00^{\mathrm{a}}$ \\
Ngombe & BAU & $1.25 \pm 0.88$ & $2.30 \pm 1.62$ & $0.62 \pm 0.36$ & $1.13 \pm 0.66$ & $3.43 \pm 2.28^{\mathrm{a}}$ \\
Kingegenyanyembe & $\mathrm{CBFM}$ & $1.21 \pm 0.74$ & $2.22 \pm 1.36$ & $0.61 \pm 0.28$ & $1.11 \pm 0.51$ & $3.33 \pm 1.87^{\mathrm{a}}$ \\
Kingegenyanyembe & BAU & $0.33 \pm 0.45$ & $0.60 \pm 0.82$ & $0.19 \pm 0.22$ & $0.35 \pm 0.40$ & $1.95 \pm 1.22^{\mathrm{b}}$ \\
Gangalamtumba & CBFM & $3.06 \pm 1.65$ & $5.61 \pm 3.02$ & $1.29 \pm 0.61$ & $2.36 \pm 1.11$ & $7.97 \pm 4.13^{\mathrm{a}}$ \\
Makota & BAU & $0.83 \pm 0.48$ & $1.52 \pm 0.89$ & $0.43 \pm 0.23$ & $0.78 \pm 0.42$ & $2.30 \pm 1.31^{\mathrm{b}}$ \\
Kidundakiyavye & CBFM & $1.25 \pm 1.01$ & $2.29 \pm 1.85$ & $0.61 \pm 0.37$ & $1.10 \pm 0.68$ & $3.39 \pm 2.53^{\mathrm{a}}$ \\
Makota & BAU & $0.83 \pm 0.48$ & $1.52 \pm 0.89$ & $0.43 \pm 0.23$ & $0.78 \pm 0.42$ & $2.30 \pm 1.31^{\mathrm{b}}$ \\
\hline
\end{tabular}

Note. Numbers after \pm are $95 \%$ confidence limits (products of standard errors of the mean and $t$-value at $95 \%$ confidence level) and means with the same letter are not significantly different using Bonferroni $t$-test $(\alpha=0.05)$.

stems $\mathrm{ha}^{-1}$ ) in Gangalamtumba, both CBFM managed miombo woodlands. Likewise, in business as usual (BAU) counterpart, the highest was $\left(3216 \pm 2254\right.$ stems $\left.\mathrm{ha}^{-1}\right)$ in Ngombe and lowest $\left(2237 \pm 2119\right.$ stems ha $\left.^{-1}\right)$ in Makota. This observation indicates miombo woodlands under both scenarios are densely populated and their difference is statistically not significant $(P>5 \%)$. However, basal area comparison between management practices was of significant difference $(P<5 \%)$. The average basal area ranged from $11.56 \pm 3.69$ in CBFM to $5.14 \pm 3.09$ in BAU (Table 3). The observations suggest that CBFM managed woodlands are composed of larger diameter trees compared to BAU practices. Stem density observed can be related to previous deforestation and forest degradation of miombo woodlands. According to Chidumayo, [8] stem density and basal area correlate with disturbance in miombo woodlands. Moreover, there is domination of larger trees in CBFM with average diameter of $12.26 \pm 2.92$ compared to $10.32 \pm 2.54$ from BAU and their overall volume estimated differed significantly $(P<5 \%)$.

Further analysis on vegetation structure portrayed reverse J-shaped curve in both CBFM and BAU. This suggests existence of more trees in the smaller diameter growing to lager diameter classes. It also indicates continuous recruitment in miombo woodlands and therefore possibility for sustainability. Other studies conducted in Tanzanian miombo woodlands demonstrated similar vegetation structure $[23,40,45]$.
This provides insight into how the recovery of miombo woodlands can be used in the emerging $C$ markets as a way of maximizing rural people's benefits from forest management.

3.2. Effects of Community Based Management on Biomass for Carbon Stock. In order to identify forest management strategies that maximize carbon storage, below- and aboveground carbon stock was first determined prior to feasibility analysis. The overall highest average carbon stock observed was in Gangalamtumba CBFM (7.97 $\pm 4.13 \mathrm{t} / \mathrm{ha})$ and lowest in Kingegenyanyembe BAU (1.95 $\pm 1.22 \mathrm{t} / \mathrm{ha})$. The sites comparison revealed statistically significant differences between CFM and BAU (Table 4). The exception was observed in Mandumburu CBFM and its counterpart Ngombe BAU with no significant deference, and this was not expected. This could be because leakage effect of CBFM rules impacted larger village landscape which improved biomass for carbon stock in both businesses as usual and CBFM practice.

Further analysis using stump measurement and extrapolation from basal diameter to diameter at breast height suggest incidence of extraction revealed more emission in BAU $(6.88 \pm 0.62 \mathrm{t} / \mathrm{ha})$ as compared to CBFM $(3.95 \pm 0.41 \mathrm{t} / \mathrm{ha})$ (Table 5). However, this result also suggests that forest extraction activities are occurring in land use management with different intensity. In addition, the result is supported by research that suggests that strengthened management rules and tenure in community forest help reduce forest product 
TABLE 5: Extent of woodland extraction and its corresponding emission in CBFM as compared to reference scenario $(n=244)$.

\begin{tabular}{lccccc}
\hline $\begin{array}{l}\text { Management } \\
\text { practice }\end{array}$ & $\begin{array}{c}\text { Density } \\
(\mathrm{N} / \mathrm{ha})\end{array}$ & $\begin{array}{c}\text { Basal area } \\
\left(\mathrm{m}^{2} / \mathrm{ha}\right)\end{array}$ & $\begin{array}{c}\text { Volume } \\
\text { removal } \\
\left(\mathrm{m}^{3} / \mathrm{ha}\right)\end{array}$ & $\begin{array}{c}\text { Biomass } \\
\text { removal } \\
(\mathrm{t} / \mathrm{ha})\end{array}$ & $\begin{array}{c}\text { Carbon stock } \\
\mathrm{emitted}(\mathrm{t} / \mathrm{ha})\end{array}$ \\
\hline In CBFM & $167 \pm 24$ & $5.31 \pm 2.78$ & $9.63 \pm 2.35$ & $7.89 \pm 0.3$ & $3.95 \pm 0.41$ \\
In BAU & $431 \pm 49$ & $8.29 \pm 3.32$ & $15.41 \pm 5.09$ & $13.77 \pm 0.8$ & $6.88 \pm 0.62$ \\
\hline
\end{tabular}

Note. $N$ is the number of stems ha ${ }^{-1}, G$ is the basal area $\left(\mathrm{m}^{2} \mathrm{ha}^{-1}\right)$, and $V$ is the volume $\left(\mathrm{m}^{3} \mathrm{ha}^{-1}\right)$; numbers after \pm are $95 \%$ confidence limits (products of standard errors of the mean and $t$-value at $95 \%$ confidence level).

TABLE 6: Forest area and its potential gross annual income from avoided $\mathrm{CO}_{2}$ e emissions.

\begin{tabular}{lccccc}
\hline Study site & Forest area (ha) & $\begin{array}{c}\text { Change in carbon stock } \\
(\mathrm{t} / \mathrm{ha} / \mathrm{yr})\end{array}$ & $\mathrm{CO}_{2} \mathrm{e}(\mathrm{t} / \mathrm{ha} / \mathrm{yr})$ & $\begin{array}{c}\text { Potential annual } \\
\text { income }(\$ / \text { ha/yr) }\end{array}$ & $\begin{array}{c}\text { Annual value for } \\
\text { whole forest area }(\$)\end{array}$ \\
\hline Kingegenyanyembe & 459.6 & 1.38 & 5.07 & 25.35 & $11,650.86$ \\
Gangalamtumba & 6,065 & 5.67 & 20.81 & 104.05 & $631,063.25$ \\
Kidundakiyave & 4904 & 1.09 & 4.00 & 20.00 & 98,080 \\
Mandumburu & 450 & -0.43 & -1.58 & -7.89 & $-3,551$ \\
\hline
\end{tabular}

extraction and improve forest condition [22]. Interestingly, recovery trajectory of miombo woodlands after extraction is rapidly from disturbances caused by human activities [2, 46]. Elsewhere, Syampungani (2009) have reported higher capacity to resprout/regenerate in harvested stands compared to mature, more or less untouched stands suggesting that miombo woodlands are dynamic ecosystems reacting well to appropriate levels of exploitation.

Miombo woodland tree species have extensive vertical and horizontal root systems which facilitate regeneration after cutting [8]. There is availability of stump coppices, root suckers, or suppressed saplings in the herb layer at the time of clearing $[8,47]$. This enables the woodlands to recover rapidly, however depending on the intensity of extraction and subsequent land use [2].

\subsection{Estimated Potential Gross Revenue from Carbon Project} Development. The determinants of feasibility of carbon project development include the amount of carbon stock observed, historical business as usual, carbon price, and associated costs $[31,48]$. Carbon price negotiations are still going on $[26,49]$. The voluntary carbon market is currently one of the main frameworks within which carbon stock can be sold from CBFM $[23,48]$. In this market, the minimum price per ton of carbon is about 5 USD during the last quarter of 2015 (Bayon et al., 2007) [23]. However, offsets that deliver complementary benefits such as biodiversity conservation and poverty reduction are likely to command a premium (Bayon et al., 2007) [26]. Using this minimum price $\left(5 \mathrm{USD} / \mathrm{tCO}_{2} \mathrm{e}\right)$ from voluntary carbon market, different study sites portrayed different potential in carbon credit sales. The Gangalamtumba miombo woodland revealed higher revenue $(631,063.25 \$)$, followed by Kidundakiyave $(98,080 \$)$ and Kingegenyanyembe (11,650.86 \$), and Mandumburu had negative results $(-3,551 \$)$ (Table 6).

These results show potential gross annual income from avoided carbon stock emission with clear differences between study sites in terms of carbon stock change, area, and expected income. The differences in carbon stock change could be contributed to management effectiveness and the condition of the baseline used. However, negative result from Mandumburu could be related to baseline used and the issue of effectiveness in forest management.

3.3.1. Estimation of the Annual Net Benefits from Avoided Carbon Stock Emissions. The annual net benefits are calculated as the difference between the annual gross revenue and total annual costs. Taking into account important costs linked to management, opportunity, and transaction cost elements, net benefit that can be anticipated from carbon credit project development in miombo woodlands of Tanzania was determined. This analysis revealed higher transaction and opportunity costs in Gangalamtumba and Kidundakiyave (Table 7). Management cost is based on local control and already developed CBFM institutions as established in Tanzania (Zahabu, 2008). In order to be profitable the gross annual revenue from sales of carbon should be high enough to cover all the costs related CBFM and carbon credit project development.

However, estimates of these cost elements may change over time and these changes must be taken into account [49]. For example, one of the main challenges related to opportunity cost is to know if what is paid is close to the alternative [48]. Further studies are still necessary to be able to generate local and national cost rates that can be useful in making cost estimates for carbon project development process. In this paper it was plausible to apply local cost estimation likely to be considered in carbon project development in Tanzania.

3.4. Carbon Project Evaluation for Economic Feasibility Decision. Before elaborating the feasibility results, the assumption which was used for this analysis considers only incremental costs and incremental benefit and therefore the net benefits and cost are the difference between business as usual situation and the project situation. Carbon project period is 20 years and discount rate is $10 \%$ per year based on central bank of Tanzania [50]. Then project evaluation was presented in three traditional forms of net present value (NPV), internal 
TABLE 7: Estimated costs and net benefit of improved carbon stock in voluntary market.

\begin{tabular}{lcccccc}
\hline Study site & $\begin{array}{c}\text { Management } \\
\text { cost }(\$ / \mathrm{yr})\end{array}$ & $\begin{array}{c}\text { Opportunity } \\
\text { cost }(\$ / \mathrm{yr})\end{array}$ & $\begin{array}{c}\text { Transaction cost } \\
(\$ / \mathrm{yr})\end{array}$ & $\begin{array}{c}\text { Total annual cost } \\
(\$)\end{array}$ & $\begin{array}{c}\text { Value of avoided } \\
\text { carbon stock }(\$ / \mathrm{yr})\end{array}$ & $\begin{array}{c}\text { Net benefit from } \\
\text { improved carbon } \\
\text { stock }(\$ / \mathrm{yr})\end{array}$ \\
\hline Kingegenyanyembe & 1,580 & $2,389.92$ & 919.2 & $4,889.12$ & $11,650.86$ & $6,761.74$ \\
Gangalamtumba & 1,580 & 31,538 & 12,130 & 45,248 & $631,063.25$ & $585,815.25$ \\
Kidundakiyave & 1,580 & $25,500.8$ & 9,808 & $36,888.8$ & 98,080 & $61,191.20$ \\
Mandumburu & 1,580 & 2,340 & 900 & 4,820 & $-3,551$ & $-8,371.00$ \\
\hline Overall & & & & & $645,397.19$ \\
\hline
\end{tabular}

TABLE 8: Feasibility test based on estimated cost and benefits of improved carbon stock in CBFM.

\begin{tabular}{|c|c|c|c|c|c|c|c|}
\hline Operation & Year & $\begin{array}{l}\text { Cost } \\
(\$ / h a)\end{array}$ & $\begin{array}{l}\text { Benefit } \\
(\$ / h a)\end{array}$ & $\begin{array}{l}\text { Discount } \\
\text { factor }\end{array}$ & $\begin{array}{l}\text { PV (cost) } \\
\text { (\$/ha) }\end{array}$ & $\begin{array}{l}\text { PV (benefit) } \\
(\$ / \text { ha })\end{array}$ & $\begin{array}{l}\text { NPV } \\
\text { (\$/ha) }\end{array}$ \\
\hline & 1 & 7.43 & 13.58 & 0.91 & 7 & 12 & 6 \\
\hline & 5 & 37.15 & 67.9 & 0.62 & 23 & 42 & 19 \\
\hline & 10 & 74.3 & 135.8 & 0.39 & 29 & 52 & 24 \\
\hline & 15 & 111.45 & 203.7 & 0.24 & 27 & 49 & 22 \\
\hline & 20 & 148.6 & 271.6 & 0.15 & 22 & 40 & 18 \\
\hline \multirow[t]{2}{*}{ Interest rate $(/ y)$} & 0.10 & & & Total & 107 & 196 & 89 \\
\hline & & & & & Benefit-cost ratio & 1.83 & \\
\hline
\end{tabular}

rate of return (IRR), and benefit-cost ration ( $\mathrm{B} / \mathrm{C}$ ratio) (Table 8).

Net present value $(\mathrm{NPV})=89(\$ / \mathrm{ha})$ and benefit-cost ration equals 1.83 which is more than 1 . Based on these criteria it is worth developing carbon project under CBFM of Tanzanian miombo woodlands. Moreover there is possibility of additional revenue from CBFM management apart from carbon credit sale. One study of CBFM found total revenues gaining to each village just about US\$ 540 and US\$ 720 per village per year [51]. The average revenue from forest product is about US\$ 630 per year; this additional revenue emanated from sustainable collection of miombo woodland products and provision of other services. Together with carbon credit the amount could be very significant return from CBFM to cover the costs imposed to the local communities and therefore contribute to the climate change mitigation and sustainable development. Therefore, this study proves that carbon project development will contribute to the future improvement in social and economic welfare of the community and thus incentivize CBFM in Tanzania.

3.5. Performing Sensitivity Analysis. The key parameters with greater influence on the results of this study include management, opportunity, and transaction cost elements as well as carbon stock from improved management. Therefore to calculate the effect of probability of change in key variable, this study performed simulations on the following scenario.

Scenario 1. Because of the long time period required to improve forest biomass and develop carbon project for climate change mitigation, the costs and benefits can be influenced by the discount rate used [44] (Fisher et al., 2011). Discounting presumes that meeting the need of current generation is more important than meeting the need of future generation. Essentially, discounting involves imposing a major cost to future for the sake of a relatively small gain today. In order to assess the sensitivity of proposed project, however, the use of higher discount rates above the one used in economic analysis of this study is recommended [44]. Increasing discount rate from $10 \%$ to $15 \%$, the results revealed net present value $(\mathrm{NPV})=55 \mathrm{USD} / \mathrm{ha}$ and benefitcost ration $(\mathrm{B} / \mathrm{C})=1.83$. Therefore, sensitivity analysis in both scenarios shows net present values are positive, the IRR are also acceptable, and $\mathrm{B} / \mathrm{C}$ ratio is more than 1 . Based on these results, if any unexpected situations occur, the project will still be of worthiness.

\section{Conclusions and Recommendations}

CBFM improved biomass for carbon storage which is financially attractive. The study observed potential benefits received from carbon offset outweigh associated costs. In miombo woodlands under CBFM carbon sequestration project will obviously be an additional income source apart from other sustainably extracted nontimber forest products. This study observed positive cash flow which can be harnessed to improve livelihoods, social services, and infrastructure development. Despite the challenges of determining additionality, permanence, and reduced leakage, carbon project development is a viable option combining conservation and development. However factors such as institutional and policy context were not captured in this study and therefore need to be examined.

In combination with these factors and observed results carbon project can be more effective and feasible. Furthermore carbon market should be properly regulated to be 
privileged to community based intervention. For example, the question of whether the net benefits accrued should be reflected in a lower price to the emitter or increased benefits to the CBFM is open to debate. Moreover, research is important to optimize carbon credit in CBFM for suggesting innovative ways of costs reduction and maximize income. The empirical knowledge about how local community actually depends on miombo woodlands for their livelihood and how this translates to reliable carbon emission estimates is also important research gap. Despite these, miombo woodlands management that generates carbon revenue especially through CBFM may provide a viable and advantageous socioeconomic development alternative.

\section{Conflicts of Interest}

The authors declare that there are no conflicts of interest regarding the publication of this paper.

\section{Acknowledgments}

The authors acknowledge the financial support and cooperation received from Climate Change Impact, Mitigation and Adaptation (CCIAM), a Royal Norwegian Sponsored Program at Sokoine University of Agriculture, Morogoro, Tanzania, and the Ministry of Natural Resources and Tourism (MNRT), Forestry and Beekeeping Division (FBD), Tanzania. The authors acknowledge the district forest departments in Mufindi and Iringa rural district including local communities involved in management of miombo woodlands for proving them with data and information needed.

\section{References}

[1] T. R. Baker, J. P. G. Jones, O. R. R. Thompson et al., "How can ecologists help realise the potential of payments for carbon in tropical forest countries?" Journal of Applied Ecology, vol. 47, no. 6, pp. 1159-1165, 2010.

[2] Z. J. Lupala, L. P. Lusambo, and Y. M. Ngaga, "Management, growth, and carbon storage in miombo woodlands of Tanzania," International Journal of Forestry Research, vol. 2014, Article ID 629317, 11 pages, 2014.

[3] R. Vinya, Stem hydraulic architecture and xylem vulnerability to cavitation for miombo woodlands canopy tree species [Ph.D. dissertation], University of Oxford, 2010.

[4] J. P. Croxall, S. H. M. Butchart, B. Lascelles et al., "Seabird conservation status, threats and priority actions: a global assessment," Bird Conservation International, vol. 22, no. 1, pp. 1-34, 2012.

[5] M. Williams, C. M. Ryan, R. M. Rees, E. Sambane, J. Fernando, and J. Grace, "Carbon sequestration and biodiversity of regrowing miombo woodlands in Mozambique," Forest Ecology and Management, vol. 254, no. 2, pp. 145-155, 2008.

[6] P. K. T. Munishi, S. Mringi, D. D. Shirima, and S. K. Linda, "The role of miombo woodlands of Southern Highlands of Tanzania as carbon sinks," Journal of Ecology and the Natural Environment, vol. 2, no. 12, pp. 261-269, 2010.

[7] I. M. Bond, B. Chambwera, M. Jones, M. Chunduma, and I. Nhantumbo, REDD+ in Dryland Forests: Issues and Prospects for Pro-Poor REDD in the Miombo Woodlands of Southern Africa
Natural Resources, Natural Resource Issues no. 21, International Institute for Environment and Development, London, UK, 2010.

[8] E. N. Chidumayo, "Forest degradation and recovery in a miombo woodland landscape in Zambia: 22 years of observations on permanent sample plots," Forest Ecology and Management, vol. 291, pp. 154-161, 2013.

[9] L. Miles, K. Kabalimu, B. Bahane et al., Carbon, Biodiversity and Ecosystem Services: Exploring Benefits. Tanzania, United Nations Environment Programme World Conservation Monitoring Centre, Cambridge, UK, 2009.

[10] P. A. Dewees, B. M. Campbell, Y. Katerere et al., "Managing the miombo woodlands of southern Africa: policies, incentives and options for the rural poor," Journal of Natural Resources Policy Research, vol. 2, no. 1, pp. 57-73, 2010.

[11] FAO, Global Forest Resources Assessment 2010: Country Report, United Republic of Tanzania, Food and Agriculture Organization of the United Nations, Rome, Italy, 2010.

[12] URT, National Forest Resources Monitoring and Assessment (NAFORMA) of Tanzania Mainland: Main Report, The Ministry of Natural Resources and Tourism, United Republic of Tanzania, 2015, http://www.tfs.go.tz/resources/view/naforma-report2015.

[13] W. F. Mwase, Å. Bjørnstad, J. M. Bokosi, M. B. Kwapata, and B. Stedje, "The role of land tenure in conservation of tree and shrub species diversity in miombo woodlands of southern Malawi," New Forests, vol. 33, no. 3, pp. 297-307, 2007.

[14] F. L. Godoy, K. Tabor, N. D. Burgess, B. P. Mbilinyi, J. J. Kashaigili, and M. K. Steininger, "Deforestation and $\mathrm{CO}_{2}$ emissions in coastal Tanzania from 1990 to 2007," Environmental Conservation, vol. 39, no. 1, pp. 62-71, 2012.

[15] URT, National Forest Policy, Ministry of Natural Resources and Tourism, Dar es Salaam, Tanzania, 1998.

[16] W. D. Sunderlin, "Poverty alleviation through community forestry in Cambodia, Laos, and Vietnam: An assessment of the potential," Forest Policy and Economics, vol. 8, no. 4, pp. 386396, 2006.

[17] A. Maryudi, R. R. Devkota, C. Schusser et al., "Back to basics: Considerations in evaluating the outcomes of community forestry," Forest Policy and Economics, vol. 14, no. 1, pp. 1-5, 2012.

[18] C. Schusser, "Who determines biodiversity? An analysis of actors' power and interests in community forestry in Namibia," Forest Policy and Economics, vol. 36, pp. 42-51, 2013.

[19] K. K. Shrestha and P. McManus, "The embeddedness of collective action in Nepalese community forestry," Small-Scale Forestry, vol. 6, no. 3, pp. 273-290, 2007.

[20] R. K. Pokharel, "Factors influencing the management regime of Nepal's community forestry," Forest Policy and Economics, vol. 17, pp. 13-17, 2012.

[21] J. Paavola, "Livelihoods, vulnerability and adaptation to climate change in Morogoro, Tanzania," Environmental Science \& Policy, vol. 11, no. 7, pp. 642-654, 2008.

[22] L. Mbwambo, T. Eid, R. E. Malimbwi, E. Zahabu, G. C. Kajembe, and E. Luoga, "Impact of decentralised forest management on forest resource conditions in Tanzania," Forests, Trees and Livelihoods, vol. 21, no. 2, pp. 97-113, 2012.

[23] Z. J. Lupala, L. P. Lusambo, Y. M. Ngaga, and A. A. Makatta, "The land use and cover change in miombo woodlands under community based forest management and its implication to climate change mitigation: a case of southern highlands of Tanzania," International Journal of Forestry Research, vol. 2015, 11 pages, 2015. 
[24] S. Charnley and M. R. Poe, "Community forestry in theory and practice: Where are we now?" Annual Review of Anthropology, vol. 36, pp. 301-336, 2007.

[25] B. B. K. Chhetri, F. H. Johnsen, M. Konoshima, and A. Yoshimoto, "Community forestry in the hills of Nepal: Determinants of user participation in forest management," Forest Policy and Economics, vol. 30, pp. 6-13, 2013.

[26] P. Newton, J. A. Oldekop, G. Brodnig, B. K. Karna, and A. Agrawal, "Carbon, biodiversity, and livelihoods in forest commons: synergies, trade-offs, and implications for REDD+," Environmental Research Letters, vol. 11, no. 4, Article ID 044017, 2016.

[27] UN-REDD Programme, Background Analysis of REDD Regulatory Frameworks, Forest Degradation in Developing Countries, Geneva, Switzerland, 2009.

[28] A. Angelsen, M. Brockhaus, M. Kanninen, E. Sills, W. D. Sunderlin, and S. Wertz-Kanounnikoff, Eds., Realising REDD+: National Strategy and Policy Options, CIFOR, Bogor, Indonesia, 2009.

[29] J. W. den Besten, B. Arts, and P. Verkooijen, "The evolution of REDD+: an analysis of discursive-institutional dynamics," Environmental Science \& Policy, vol. 35, pp. 40-48, 2014.

[30] T. Treue, Y. M. Ngaga, H. Meilby et al., "Does participatory forest management promote sustainable forest utilisation in Tanzania?" International Forestry Review, vol. 16, no. 1, pp. 2338, 2014.

[31] B. P. Sharma, M. Nepal, B. S. Karky, S. K. Pattanayak, and P. Shyamsundar, "Baseline considerations in designing REDD+ pilot projects: evidences from nepal," SANDEE Working Paper, 2015.

[32] E. Sungusia and J. F. Lund, "Against all policies: landscape level forest restoration in Tanzania," World Development Perspectives, vol. 3, pp. 35-37, 2016.

[33] K. John, D. S. A. Silayo, and A. Vatn, "The cost of managing forest carbon under REDD+ initiatives: a case of kolo hills forests in kondoa district, dodoma, tanzania," International Journal of Forestry Research, 12 pages, 2014.

[34] A. Angelsen, How do we set the reference levels for REDD payments? In Moving ahead with REDD: issues, options and implications, Center for International Forestry Research (CIFOR), Bogor, Indonesia, 2008.

[35] C. Luttrell, L. Loft, M. F. Gebara et al., "Who should benefit from REDD+? Rationales and realities," Ecology and Society, vol. 18, no. 4, article 52, 2013.

[36] L. Peskett and K. Todd, Putting REDD+ Safeguards and Safeguard Information Systems into Practice. Policy Brief, vol. 3, UNREDD, Geneva, Switzerland, 2013.

[37] K. MacDicken, "A guide to monitoring carbon storage in forestry and agroforestry projects," Tech. Rep. 1611 N, Winrock International Institute for Agricultural, 1997.

[38] MNRT, National Forestry Resources Monitoring and Assessment (NAFORMA) of Tanzania, Field Manual, Biophysical Survey, Ministry of Natural Resources \& Tourism, Dar Es Salaam, Tanzania, 2010.

[39] IPCC, Good Practice Guidance for Land-Use Changes and Forestry, Institute of Environmental Strategies, Kanagawa, Japan, 2003.

[40] W. A. Mugasha, T. Eid, O. M. Bollandsås et al., "Allometric models for prediction of above- and belowground biomass of trees in the miombo woodlands of Tanzania," Forest Ecology and Management, vol. 310, pp. 87-101, 2013.
[41] E. W. Mauya, W. A. Mugasha, E. Zahabu, O. M. Bollandsås, and T. Eid, "Models for estimation of tree volume in the miombo woodlands of Tanzania," Southern Forests, vol. 76, no. 4, pp. 209-219, 2014.

[42] Peters-Stanley, "Back to the future: state of the Voluntary carbon markets," Forest Trends, Ecosystem Marketplace Report, 2012.

[43] M.-G. Piketty, I. Drigo, P. Sablayrolles, E. A. De Aquino, D. Pena, and P. Sist, "Annual cash income from community forest management in the Brazilian Amazon: Challenges for the future," Forests, vol. 6, no. 11, pp. 4228-4244, 2015.

[44] R. Perman, Y. Ma, M. Common, D. Maddison, and J. McGilvray, Natural Resource and Environmental Economics, Pearson, Edinburgh, UK, 4th edition, 2011.

[45] E. E. Mwakalukwa, H. Meilby, and T. Treue, "Floristic composition, structure, and species associations of dry miombo woodland in Tanzania," ISRN Biodiversity, vol. 2014, Article ID 153278, 15 pages, 2014.

[46] F. K. Kalaba, C. H. Quinn, A. J. Dougill, and R. Vinya, "Floristic composition, species diversity and carbon storage in charcoal and agriculture fallows and management implications in Miombo woodlands of Zambia," Forest Ecology and Management, vol. 304, pp. 99-109, 2013.

[47] P. G. H. Frost, "The ecology of miombo woodlands," in The Miombo in Transition: Woodlands and Welfare in Africa, pp. 1157, Center for International Forest Research (CIFOR), Bongor, Indonesia, 1996.

[48] J. Pelletier, N. Gélinas, and M. Skutsch, "The place of community forest management in the REDD+ landscape," Forests, vol. 7, no. 8, article 170, pp. 1-24, 2016.

[49] D. J. Sonwa, J. H. Nlom, and S. G. Neba, "Valuation of forest carbon stocks to estimate the potential for result-based payment under REDD+ in Cameroon," International Forestry Review, vol. 18, supplement 1, pp. 119-129, 2016.

[50] URT, Tanzania's National REDD-Redness Programme, Division of Environment, Vice-President's Office, Dar es Salaam, Tanzania, 2009.

[51] J. C. Ribot, "Forestry and democratic decentralization in subSaharan Africa. A rough review," in Governing Africas Forests in a Globalized Word, L. A. German, A. Karsenty, and A. M. Tiani, Eds., pp. 29-55, Center for International Forestry Research, Earth Scan, London, UK, 2010. 

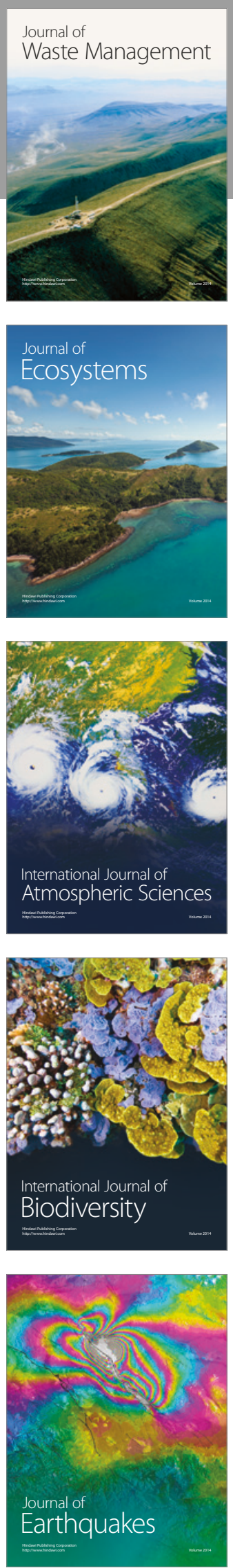
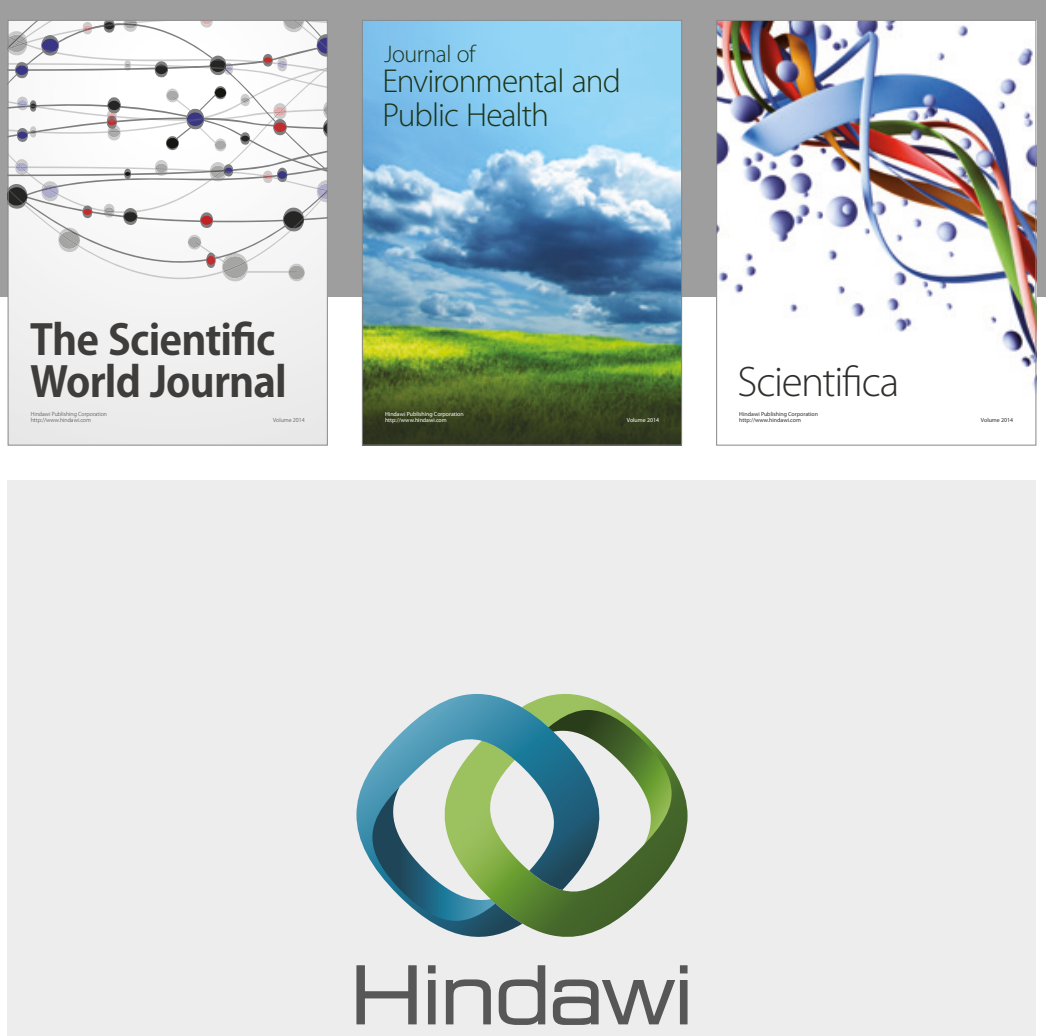

Submit your manuscripts at

https://www.hindawi.com
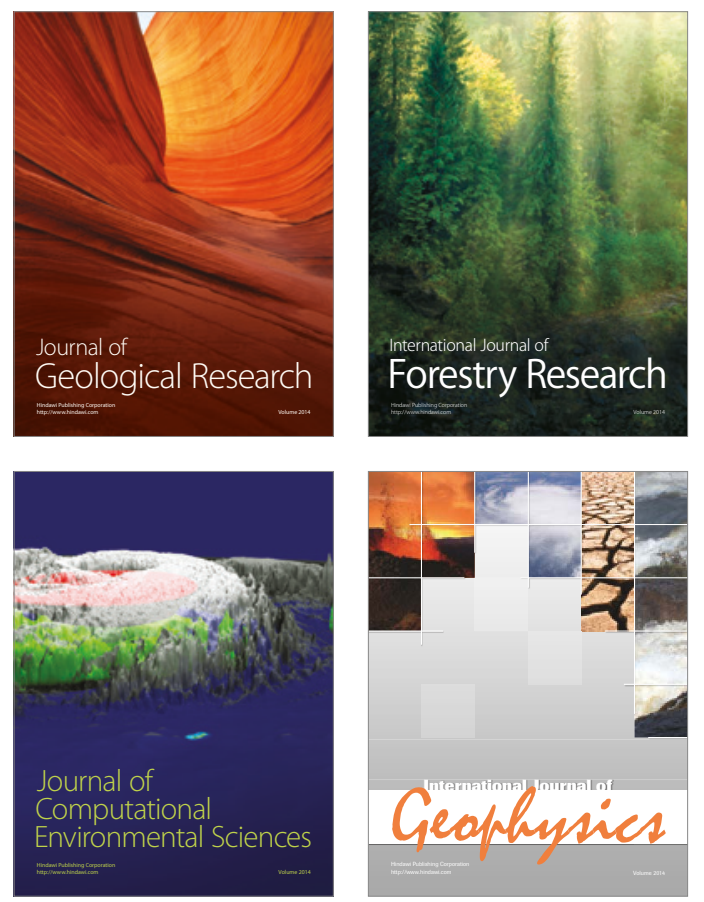
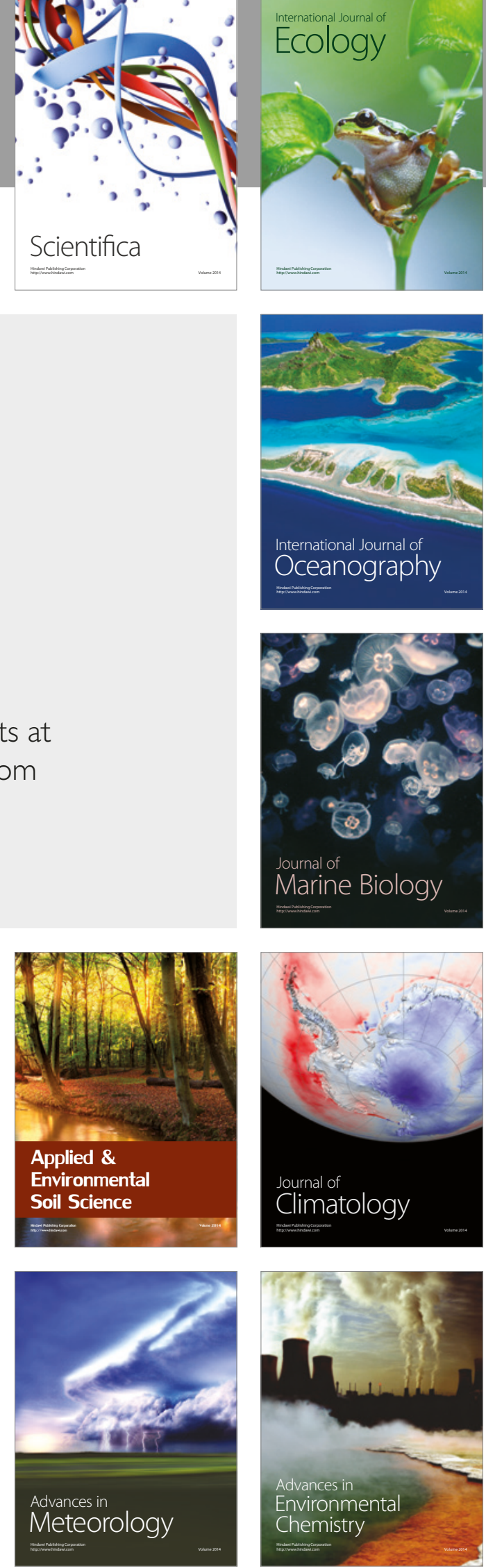